\title{
MICROMECHANISMS OF FRACTURE OF MAGNESIUM BASED COMPOSITE AFTER SUPERPLASTIC DEFORMATION
}

\author{
B. Ballóková, K. Sülleiová, M. Besterci, O. Velgosová, S.J. Huang
}

\begin{abstract}
The micromechanisms of fracture of $\mathrm{AZ61}+1 \mathrm{wt} . \% \mathrm{Al}_{2} \mathrm{O}_{3}$ composite in the zone of superplastic deformation was analysed and quantified in this work. The specimens were tested at temperature of $200^{\circ} \mathrm{C}$ at different strain rates. Changing the strain rate, from $1 \times 10^{-2} \mathrm{~s}^{-1}$ to $1 \times 10^{-4} \mathrm{~s}^{-1}$, a significant growth of ductility was observed. At maximum value of superplasticity the fracture was transcrystalline ductile with dimples of two size categories. Based on the statistical analysis of fracture micromechanisms at the elevated temperature and strain rates of $10^{-0}$ $1 \times 10^{-4} \mathrm{~s}^{-1}$ hyperbolic dependency was depicted according to Gurland Plateau theory.
\end{abstract}

Keywords: Mg Alloy AZ61, fracture analysis, superplastic behaviour

\section{INTRODUCTION}

Many researchers attempt to fabricate Mg-based metal matrix composites by different methods in order to obtain light-weight materials with excellent mechanical properties [1-4]. Magnesium based nanocomposites (AZ 91 with different weight percent of $\mathrm{Al}_{2} \mathrm{O}_{3}$ particles) were studied in [5,6], where the effect of nano-alumina particles and heat treatment on microstructure, mechanical properties and failure mechanism were investigated.

Superplasticity in polycrystalline materials is facilitated by dynamic modifications in the microstructure. Retrieval of the superplastic microstructure at elevated temperatures rests on the ability to maintain dynamic recovery. The strain rate is defined by Mukherjee equation:

$$
\varepsilon=\frac{K D G b}{k T}\left(\frac{b}{d}\right)^{p}\left(\frac{\sigma}{G}\right)^{\frac{1}{m}}
$$

where $D$ is a diffusion coefficient, $T$ - temperature, $d$ - grain size, $p$ - grain size exponent (23 ), and $m$ - stress exponent (0.4-0.7).

The primary deformation mechanism in superplastic materials is a grain boundary sliding with stress accommodation by diffusion or dislocation movement. According to (1) finer grains (smaller than $10 \mu \mathrm{m}$ ), equiaxed grains with large angle boundaries and higher strain rate are essential to obtain superplasticity at a given stress. Superplasticity is maintained if the dynamic growth of grains is minimized. However, superplasticity can be limited by cavitation on the grain boundaries.

Beáta Ballóková, Katarína Sülleiová, Michal Besterci: Institute of Materials Research, Slovak Academy of Sciences, Watsonova 47, 04001 Košice, Slovakia

Oksana Velgosová: Institute of Materials, Faculty of Metallurgy, Technical University in Košice, Park Komenského 11, 04200 Košice, Slovakia

Song-Jeng Huang: National Taiwan University of Science and Technology, Department of Mechanical Engineering, 43, Sec.4, Keelung Rd., Taipei, 106, Taiwan, R.O.C. 
The aim of this paper is to analyze and quantify the fracture mechanisms of AZ61$\mathrm{Al}_{2} \mathrm{O}_{3}$ magnesium system with 1 wt. $\%$ of $\mathrm{Al}_{2} \mathrm{O}_{3}$ phase, tested in tensile mode at temperature of $200^{\circ} \mathrm{C}$ and strain rates of $10^{0}-1 \times 10^{-4} \mathrm{~s}^{-1}$.

\section{EXPERIMENTAL MATERIALS AND METHODS}

The matrix used in this work is magnesium alloy AZ61 made by Metaltech Industrial Co, LTD, Taiwan. The chemical composition is shown in Table 1.

Tab.1. Chemical composition of AZ61.

\begin{tabular}{|l|l|l|l|l|l|l|l|l|}
\hline Elements & $\mathrm{Al}$ & $\mathrm{Mn}$ & $\mathrm{Zn}$ & $\mathrm{Si}$ & $\mathrm{Fe}$ & $\mathrm{Cu}$ & $\mathrm{Ni}$ & $\mathrm{Mg}$ \\
\hline wt. \% & 5.95 & 0.26 & 0.64 & 0.009 & 0.005 & 0.0008 & 0.0007 & balance \\
\hline
\end{tabular}

Particles $\mathrm{Al}_{2} \mathrm{O}_{3}$ with the weight fraction of $1 \%$ are used as the reinforcement phase. The commercially available $\mathrm{Al}_{2} \mathrm{O}_{3}$ powder with a particle diameter about $20 \mathrm{~nm}$ with the purity of $\geq 99.8 \%$ is added into AZ61 to form Mg-based metal-matrix composite.

The melt-stirring technique was used to fabricate the present $\mathrm{Mg}$ composites. The AZ61 and $\mathrm{Al}_{2} \mathrm{O}_{3}$ particles were initially placed inside a graphite crucible and heated to $400^{\circ} \mathrm{C}$ in a resistance-heated furnace, then a stirring vane functioned; meanwhile, $\mathrm{CO}_{2}$ and $\mathrm{SF}_{6}$ gushed from the gas tank into the crucible to mixture the melt. $\mathrm{CO}_{2}$ and $\mathrm{SF}_{6}$ also prevented the melt from oxidation. The crucible was continuously heated up to $700^{\circ} \mathrm{C}$, and then the molten alloy was stirred with a vane operated at $350 \mathrm{rev} / \mathrm{min}$ for 3 minutes. Finally, the composite melt was poured into a metallic mould.

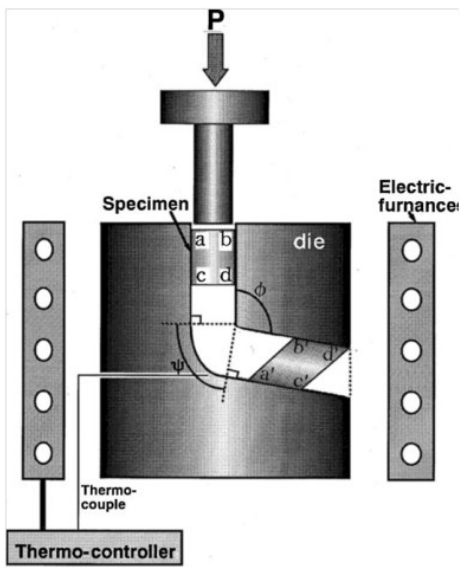

Fig.1. Scheme of the equal-channel angular pressing (ECAP).

The magnesium composite containing 1 wt. $\%$ of $\mathrm{Al}_{2} \mathrm{O}_{3}$ were prepared for further mechanical testing. ECAP was carried out in a die with the die angle of $\Phi=120^{\circ}$. The scheme of ECAP is shown in Fig. 1. The deformation temperature was set at $300 \pm 10^{\circ} \mathrm{C}$. During deformation, the plunger speed was about $1.0 \mathrm{~mm} / \mathrm{s}$. After each extrusion pass, the billet was quenched into water. The billets were rotated counterclockwise around the exit extrusion axis by $90^{\circ}$ between each pass, the so-called Bc route, and each bar was ECAPed by 4 passes. From these composite materials (Ø3 and $30 \mathrm{~mm}$ long) were prepared the 
specimens for tensile testing. Analyses of the deformation behaviour were performed by the tensile deformation at temperatures $200^{\circ} \mathrm{C}$ and strain rates of $10^{-2}-1 \times 10^{-4} \mathrm{~s}^{-1}$.

\section{RESULTS AND DISCUSSION}

Microstructure parameters of the system, namely the matrix grain size, the mean size of the dispersed particles and their average distance before and after ECAP were evaluated. The microstructure of the starting material (before ECAP) was heterogeneous with the grain size of $25-30 \mu \mathrm{m}$. The grains sizes of material after ECAP decreased on the values of approx. $0.7 \mu \mathrm{m}$. The mean size was estimated by the measurement of $50-100$ grains. Fine $\mathrm{Al}_{2} \mathrm{O}_{3}$ particles observed by TEM were distributed randomly as well as in clusters. $\mathrm{Al}_{2} \mathrm{O}_{3}$ particles size of approx. $20 \mathrm{~nm}$ and their clusters were localized on the grain boundaries and in the grains.

Figure 2 shows the nominal stress according to true strain at $200^{\circ} \mathrm{C}$ for samples with $1 \%$ of $\mathrm{Al}_{2} \mathrm{O}_{3}$ phase pressed by 4 passes after tensile deformation. It was found that the experimental material had maximal superplasticity at temperature of $200^{\circ} \mathrm{C}$ and strain rate of $1 \times 10^{-4} \mathrm{~s}^{-1}$ what is in an agreement with [7,8] for the commercial alloy AZ61Mg. A probable mechanism of superplasticity is the high angle grain boundary sliding. Strength properties decreased with the higher test temperature.

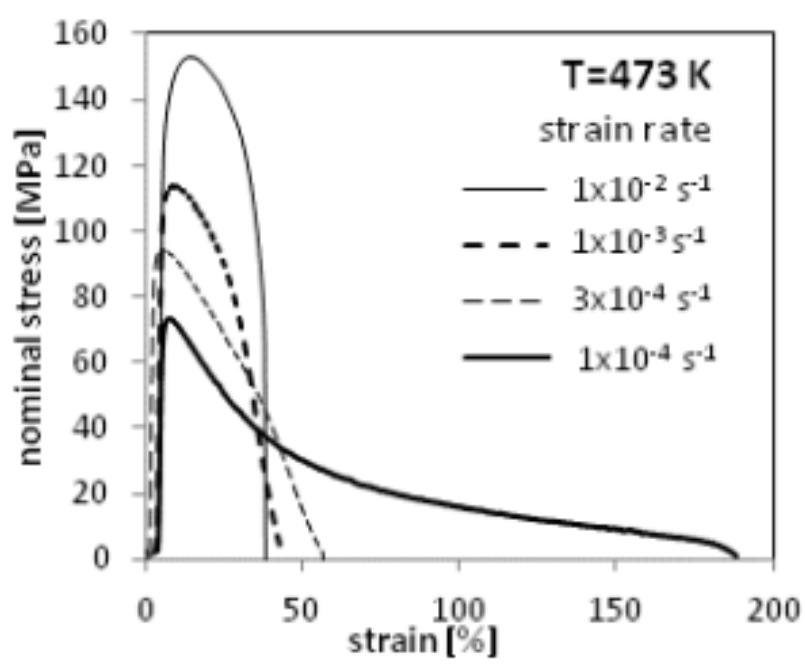

Fig. 2 Nominal stress vs. true strain for samples tested at different strain rates.

Fracture micromechanisms were analyzed over the strain rates range at temperature of superplastic deformation of $200^{\circ} \mathrm{C}$. Fractures had the transcrystalline ductile dimple character. The mean diameter of dimples was evaluated from the file of $150-200$ dimples. Larger dimples were created on $\mathrm{Mg}_{17} \mathrm{Al}_{12}$ particles, smaller ones on the dispersed $\mathrm{Al}_{2} \mathrm{O}_{3}$ particles. According to Gurland - Plateau theory, [9] the ductile fracture has three stages: initiation, growth and coalescence of cavities, Fig. 3. Cracks were created on the particle - matrix interphases and presumably in the triple junctions of the grains of the matrix [10]. 

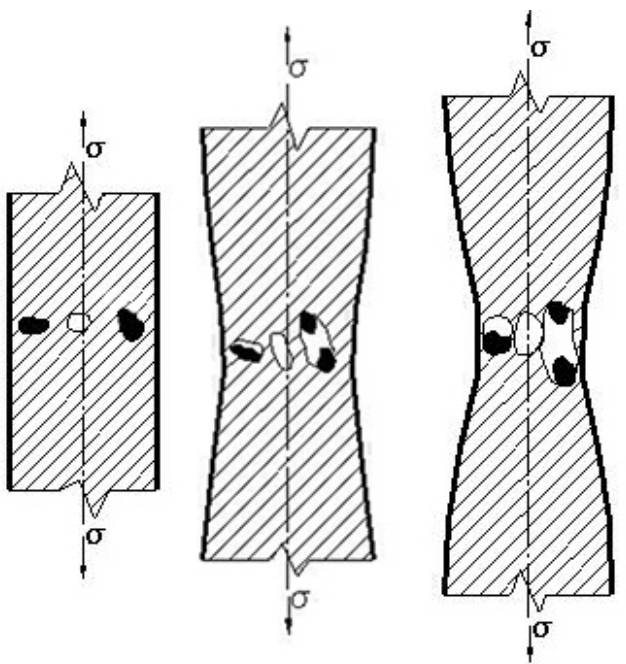

Fig.3. The model of three stages of transcrystalline ductile fracture: a) initiation, b) growth of cavities, c) coalescence of cavities.

Fractures for the each strain rate are shown in Figs. $4-8$, the dependence of the dimples diameter on the strain rate are indicated in Table 2. The whole set of dimples created during the plastic deformation of particles in both secondary phases was used in statistics.

Tab.2. Dependence of average dimples size/diameter on strain rate.

\begin{tabular}{|l|l|l|l|l|l|}
\hline Strain rate $\left[\mathrm{s}^{-1}\right]$ & $10^{0}$ & $10^{-1}$ & $10^{-2}$ & $10^{-3}$ & $10^{-4}$ \\
\hline Dimples diameter $[\mu \mathrm{m}]$ & 8 & 6 & 2 & 1 & 0.8 \\
\hline
\end{tabular}

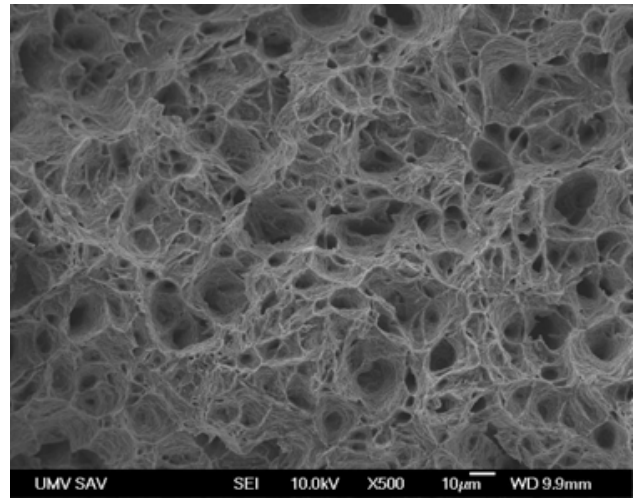

Fig. 4. Transcrystalline ductile fracture at $200^{\circ} \mathrm{C}$ and strain rate of $10^{0} \mathrm{~s}^{-1}$.

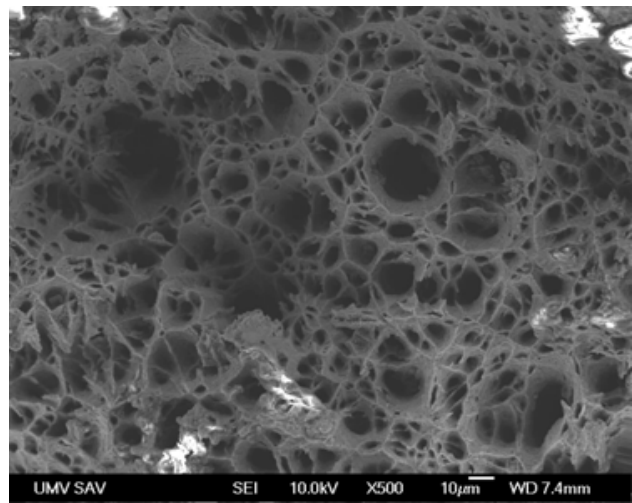

Fig. 5. Transcrystalline ductile fracture at $200^{\circ} \mathrm{C}$ and strain rate of $10^{-1} \mathrm{~s}^{-1}$. 


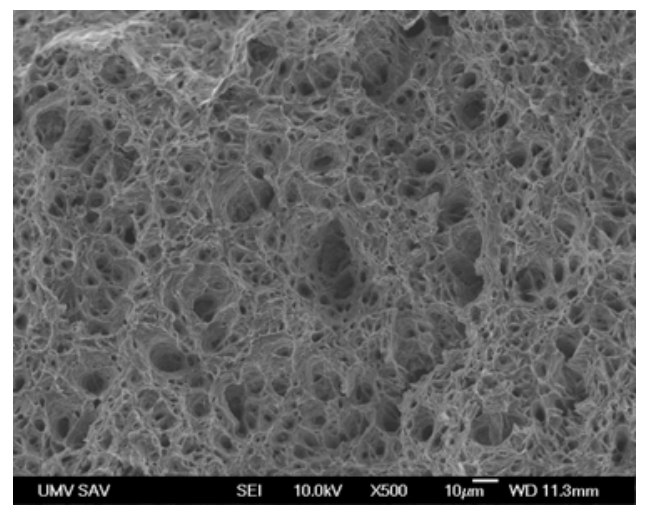

Fig. 6. Transcrystalline ductile fracture at $200^{\circ} \mathrm{C}$ and strain rate of $10^{-2} \mathrm{~s}^{-2}$.

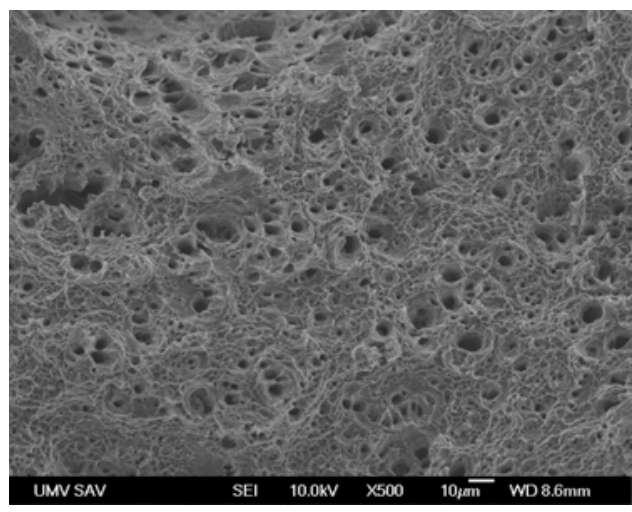

Fig. 7. Transcrystalline ductile fracture at $200^{\circ} \mathrm{C}$ and strain rate of $10^{-3} \mathrm{~s}^{-3}$.

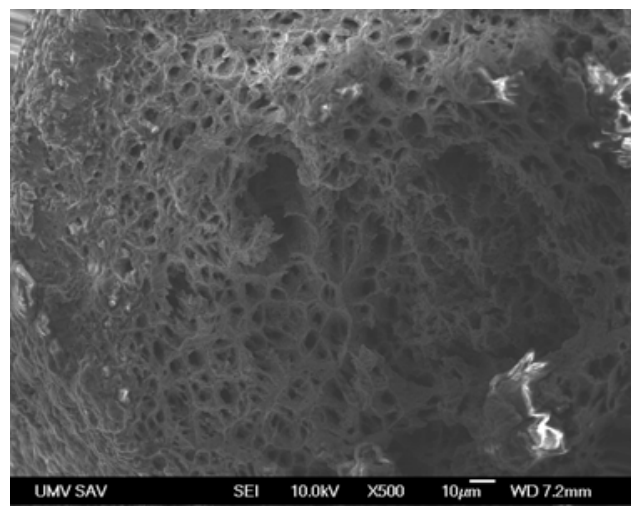

Fig. 8. Transcrystalline ductile fracture at $200^{\circ} \mathrm{C}$ and strain rate of $10^{-4} \mathrm{~s}^{-4}$.

The average dimples diameter decreases with decreasing strain rate and at the constant temperature $\left(200^{\circ} \mathrm{C}\right)$. It is evident that besides decohesion on the particles $\left(\mathrm{Mg}_{17} \mathrm{Al}_{12}\right.$ and $\left.\mathrm{Al}_{2} \mathrm{O}_{3}\right)$ - matrix interphases, dimples were initiated in the triple junctions of nanomaterials. Growth of initiation centres led to growth reduction of the mean dimple size and high reduction of area.

\section{CONCLUSION}

Based on the extensive experimental studies of micromechanisms of failure after superplastic deformation of $\mathrm{AZ61} \mathrm{Mg}-\mathrm{Al}_{2} \mathrm{O}_{3}$ composite the following results were obtained. The maximum value of superplasticity approx. $180 \%$ was reached at the temperature of $200^{\circ} \mathrm{C}$ and strain rate of $1 \times 10^{-4} \mathrm{~s}^{-1}$. A probable mechanism of superplasticity is the high angle grain boundary sliding. The fracture was transcrystalline ductile with dimples of two size categories. Larger dimples were created on $\mathrm{Mg}_{17} \mathrm{Al}_{12}$ particles, smaller ones on the dispersed $\mathrm{Al}_{2} \mathrm{O}_{3}$ particles. Based on the statistical analysis of fracture micromechanisms at the temperature of $200^{\circ} \mathrm{C}$ and strain rates of $10^{-0}-1 \times 10^{-4} \mathrm{~s}^{-1}$ hyperbolic dependency according to Gurland - Plateau theory. 


\section{Acknowledgement}

The work was supported by the Slovak National Grant Agency under the Project VEGA 2/0118/14

\section{References}

[1] Cao, G., Choi, H., Oportus, J., Konishi, H., Li, X.: Mat. Sci. Eng. A, vol. 494, 2008, p. 127

[2] Ugandhar, S., Gupta, M., Sinha, SK.: Composite Structures, vol. 72, 2006, p. 206

[3] Hassan, SF., Gupta, M.: J. of Alloys and Compounds, vol. 419, 2006, p. 84

[4] Hassan, SF., Gupta, M.: Mat. Sci. Eng. A, vol. 392, 2005

[5] Shanti, M., Tun, KS., Pandey, RS., Gupta, M.: Kovove Mater., vol. 49, 2011, p. 197

[6] Lin, PC., Huang, SJ., Hong, PS.: Acta Metallurgica Slovaca, vol. 16, 2010, p. 237

[7] Matsubara, K., Miyahara, Y., Horita, Z., Langdon, TG.: Metall. Mater. Trans. A, vol. 35, 2004, p. 1735

[8] Miyahara, Y., Matsubara, K., Horita, Z., Langdon, YG.: Metall. Mater. Trans. A, vol. 36, 2005, p. 1705

[9] Gurland, J., Plateau, J.: Trans. ASM, vol. 56, 1963, p. 442

[10] Besterci, M., Sülleiová, K., Kvačkaj, T.: Kovove Mater., vol. 46, 2008, p. 309 